\title{
Higher Education Policies and Employment in Mexico
}

\author{
Ernesto Rangel1, Antonina Ivanova ${ }^{2}$ \\ ${ }^{1}$ Pacific Basin Studies Center, APEC Study Center of University of Colima, Colima, México \\ ${ }^{2}$ APEC Study Center of the Autonomous University of Southern Baja California, Tijuana, México \\ Email: erangel@ucol.mx, aivanova@uabcs.mx
}

Received 24 January 2014; revised 24 February 2014; accepted 23 March 2014

Copyright (C) 2014 by authors and Scientific Research Publishing Inc.

This work is licensed under the Creative Commons Attribution International License (CC BY).

http://creativecommons.org/licenses/by/4.0/

c) (i) Open Access

\begin{abstract}
The paper shows the situation on higher education and employment policies in Mexico based on the opinion of key persons related to the issue. Scholars, government officers and entrepreneurs participated with their opinions in a survey designed for collecting information. It is very important to know not only from the society but also from the specific policy makers that what is going vs official version in order to get some more objective information about this interesting topic. In conclusion, Mexico's higher education policies must provide a strategic vision based on the development of a coordinated industrial policy. It is imperative to improve the balance between supply and demand for professionals, whose studies are based on policies designed to improve Mexico's productive structure and its integration into the international economy.
\end{abstract}

\section{Keywords}

\section{Higher Education, Employment, Policies, Mexico}

\section{Introduction}

A recent UNESCO document [1] emphasizes that while the number of students in higher education increases, greater attention must be paid to the quality of the graduating student skills and their relation to real-world workplace demands. There are many studies on the links between higher education, employment and economic performance [2] [3] and regional analysis for Latin America [4]-[7], Asia and the Pacific [8]-[11]. As both part of Latin America and part of the Pacific Rim, Mexico shares many of the characteristics and problems presented in these studies [9] [10] [12]-[14]. The current global recession shows that employment problems are generated by the supply side because many graduates do not have the skills required by the labor market [2] [3] [15]. According to the latest data available from the National Institute for Statistics and Geography (INEGI, in Spanish), 
there are currently 2.7 million unemployed persons in Mexico (5.2\% of the economically active population, September 2013). Interestingly, this somewhat parallels Russia $(5.3 \%)^{1}$ and China $(6.5 \%)^{2}$, although Mexico's underemployment rate is lower. However, it is also significant to note that Mexico's underemployment rate is significantly higher than that of South Korea $(3.0 \%)^{3}$ and Japan (4.0\% in September 2013, [16]).

The economic situation in Mexico is not significantly improving and it is the same for college graduates seeking employment. A study carried out by the National Association of Universities and Institutions of Higher Education (ANUIES, in Spanish) [17] reveals that difficulty in finding employment affects $40 \%$ of university graduates, significantly affecting the total professional unemployment rate which is currently at $5.1 \%$. This rate can potentially increase significantly as Higher Education Institution (HEI) graduate unemployment will affect approximately 3 million persons in 2020. In this regard, the Special Committee on Strengthening Higher Education and Training to Promote Development and Competitiveness (CEFESCDC, in Spanish) ${ }^{4}$ suggests stakeholders:

1) Identify career opportunities in growth areas required by Mexico in order to better counsel students who are enrolling in HEIs for the first time.

2) Coordinate with businesses to better define the employee profiles they require.

3) Develop mechanisms to improve vocational guidance for students, particularly as their transition between different educational levels.

4) Adjust jointly to the great dynamism of the productive sector with greater creativity and flexibility. This, of course, requires the State to redefine its role and increase its spending on infrastructure, as well as to better define a policy that encourages innovation and takes the infrastructure of the country's productive sector into account.

5) Lay the necessary legal and institutional foundations to better articulate and coordinate public policies to better ensure improving articulation and coordination required between the state, the private sector and academia, in order to strengthen institutions of higher education so that they may improve the services and training that they provide.

The need for a public policy that more closely reflects societal needs as a whole is becoming increasingly evident, especially after the distancing caused, in part, by the very strict application of and adherence to the neoliberal model in the past few decades, which is attributable, in great part, to various international agreements such as the "Washington Consensus". At the same time, the absence of an industrial policy to provide a roadway towards production in a context that is globalized and highly competitive causes disarticulation among the different sectors that subsequently contributes to worsening the already deplorable situation that Mexico suffers with respect to economic growth, which affects the relationship between institutions of higher learning and the employment possibilities of their graduates.

François Vallaeys, a UNESCO consultant, on November 25 2013, gave a lecture titled "Institutions of Higher Education in Social Responsibility" at the University of Colima. In his lecture, Vallaeys maintained that there is a need for integrated public policies that are based on the beforehand knowledge of public policy's social effects. He also maintained that there is a need to take into account the participation of all of the affected stakeholders who are involved in the solution of environmental issues. He then spoke of a complex systemic assessment, which, without a doubt, is difficult, but which already represents challenges for universities who wish to integrate their activities within the realm of social responsibility.

Following the arguments posited by Vallaeys, in mid-2013, the authors surveyed key actors in government, business and academia, focusing on public policies pertaining to higher education, employment, and science and technology. The results of the survey are reported in the following sections. It is important to mention beforehand that the survey results, although based on perceptions, provide valuable data that shed a light on the major challenges of public policies related to higher education and employment in Mexico. After presenting the me-

\footnotetext{
${ }^{1}$ Trading economics [18].

${ }^{2}$ The only source of data available to date that indicates the real state of unemployment in urban China is the Fifth Census of 2000, which was realized based on international unemployment indices and definitions. According to this census, the unemployment rate in urban China reached $8.27 \%$ in 2000 , with a rate of $9.43 \%$ in urban and $6.24 \%$ in rural areas. This rate was one of the highest in the world in 2000 , after Italy with $11.3 \%$ and France with $10.0 \%$. Data from 2011 show unemployment at 6.5\% [19].

${ }^{3}$ Trading economics [20].

${ }^{4} \mathrm{~A}$ Mexican legislature organism created to ensure the adequate distribution of educational services within the republic. It is also responsible for ensuring the quality and plurality of educational services to. Ximena Martel Laura Cantu (PVEM), president of the Commission stated that the purpose of this Commission is to "be a forum analysis, discussion and dialogue to create legislation that promotes development and competitiveness in Mexico by strengthening higher education and training in the context of the challenges posed by the knowledge society and human development”.
} 
thodology applied, the study is divided into four parts highlighting specific policies and the relevant cross-cutting issues in the areas of higher education, employment, economics, and science and technology. The paper is concluding with some final remarks.

\section{Methodology}

As previously stated above, our research team elaborated a database to process the information we compiled from the questionnaire. It is important to note that the information about Mexico represents only one of several sections including information about other countries. This survey and database have been applied and modified over approximately 4 years and they have been modified and refined to better compile and process the information and ease the interpretation of the results to better compare and detect best practices that might be convenient to implement in Mexico. The four countries that form the basis of information are from the Northeast Pacific Basin: Japan, South Korea, China and Russia. Therefore, the information provided in the case of Mexico represents a next step in a research project that aims to identify variables and propose future actions.

The information provided in this work is specific to the modified questionnaire that was used in previous works [9] [10]. Modifications were made during early 2013 and applied during the months of May and June of that year. The subjects who were randomly selected were then contacted by email asking them to participate. Persons accepting to participate were then sent the questionnaire by email and were given two weeks to reply at their convenience, which parallels the methodology employed by Cogan [8].

The questionnaire was designed to recover opinions of a select group of renowned executives and academicians from universities, government and businesses in Mexico, persons directly involved in the elaboration and implementation of national policies. After identifying a reduced number of potential survey subjects, all recognized leaders in their respective areas, survey participants were selected randomly; however, geographically, they were selected exclusively from Mexico City, Monterrey and Guadalajara metropolitan areas, the three major areas of commercial, industrial and technological development. The goal of the questionnaire was to gather quantitative and qualitative information about their knowledge of the existence of higher education policies and their linkage to employment, economic development, and innovations in science and technology. Consequently, the questionnaire also included open-ended questions that permitted the experts to provide additional, more indepth comments. The survey participants were also asked about the application and coordination of policies and to the degree they felt they promoted professional development and provided highly trained professionals who can meet the needs of the private sector and stimulate research and development in the area of science and technology.

The questionnaire we applied consists of 37 items that are organized in the following clusters: 1) Subject Information; 2) Assessment of Higher Education Policies; 3) Assessment of Employment Policies; 4) Assessment of Economic Policies; 5) Assessment of Science and Technology Policies (Table 1).

\section{Higher Education Policies}

"In some areas, the demand for professionals is saturated because it is concentrated in the cities; however, there is an overall lack of professionals at the state level. ${ }^{5,}$

There is no doubt that there are public policies in Mexico that focus on socioeconomic issues. Many of these policies are enunciated in the National Development Plan and various programs that guide the county's efforts. However, although on one level Mexico seems to have policies, the authors of this article found it important to go beyond the assertions and official discourse of the government in turn.

The applied survey confirms that Mexico's higher education policy is readily accessible in the public domain. Results show that that $90 \%$ of the academic sector, $100 \%$ of the interviewed entrepreneurs and $100 \%$ from the government sector report they know of the existence of Mexico's higher educational policies. Given the backgrounds of the respondents, it is surprising that $7 \%$ reported not knowing of the existence of higher education policies.

In this sense, the CEFESCDC invites persons to better inform themselves about careers offered by higher education institutions so that they can select a better match between the university of their choice and employ-

\footnotetext{
${ }^{5}$ Opinions of subjects surveyed. Surveys were applied to Mexican university administrative and academic personnel, government functiona-
} ries and businessmen, 2013. 
Table 1. Cluster and questions.

\begin{tabular}{ll}
\hline \multicolumn{1}{c}{ Cluster } & Questions \\
\hline & 1) Organization name \\
2) Job title \\
3) Name of the interviewee \\
\end{tabular}

1) Do you believe higher educational policies are currently operating?

2) In your opinion, in what kind of professions should be focus the effort of the universities for a bigger development (rate from 1 to 4 , where, 1 = most important and 4 = least important): engineering and technology; management and marketing; mathematics and science; law and humanities

3) In relation to the quality and supply of graduate professionals from higher educational institutes, you consider that the current job offer is: saturate; adequate; deficient

4) What abilities and aptitudes do you consider students should develop in order to perform productively labor activities on the current job positions and that you think, have

2) Assessment of Higher Education Policies not had the adequate promotion by the higher educational institutions (Grade from 1 to 8 where, 1 = most important and 8 = least important): analytical; manuals; decision making; solving problems; using technology; team work; languages and communication; statistics

5) Do you believe that educational policies are adequate for the economic structure?

6) Do you believe that educational policies are adequate to the present international economic situation?

7) Do you believe that educational policies are linked with employment policies?

8) Do you believe that educational policies are linked with the economic policies?

9) Do you believe that educational policies are linked with science and technology policies?

Any additional comment

10) Do you believe employment policies are currently operating?

11) How do current employment policies contribute to increase of the productivity of enterprises?: a lot; a little; nothing; indifferent; don't know

12) How do current employment policies contribute to increase of the employment opportunities?: a lot; a little; nothing; indifferent; don't know

13) To what degree do you consider the knowledge and abilities of newly-employed graduates is adequate to their immediate private sector integration for?: excellent; good; more and less; poor

3) Assessment of Employment Policies

14) Do you believe employment policies are adequate for the country's economic structure?

15) Do you believe employment policies are adequate for the present international economic situation?

16) Do you believe employment policies are linked with education policies?

17) Do you believe employment policies are linked with economic policies?

18) Do you believe employment policies are linked with science and technology policies?

Any additional comment

19) Do you believe there are economic policies currently in operation?

20) How do currently economic policies contribute to increase the productivity of enterprises?: a lot; a little; nothing; indifferent; don't know

21) How do currently economic policies contribute to increase the employment opportunities?: a lot; a little; nothing; indifferent; don't know

4) Assessment of Economic Policies

22) Do you believe economic policies are adequate for the country's economic structure?

23) Do you believe economic policies are adequate for the present international economic situation?

24) Do you believe economic policies are linked with education policies?

25) Do you believe economic policies are linked with employment policies?

26) Do you believe economic policies are linked with science and technology policies?

Any additional comment 


\section{Continued}

5) Assessment of Science and Technology Policies
27) Do you believe there are science and technology policies currently operating?

28) Do you believe there is science and technology policies linked with the job offers currently operating?

29) How does currently science and technology policy contributes to increase the productivity of enterprises?: a lot; a little; nothing; indifferent; don't know

30) How does currently science and technology policy contributes to increase the employment opportunities?: a lot; a little; nothing; indifferent; don't know

31) Do you believe science and technology policies are adequate for the country's economic structure?

32) Do you believe science and technology policies are adequate to human resources supply?

33) Do you believe science and technology policies are adequate to the present international economic situation?

34) Do you believe science and technology policies are linked with education policies?

35) Do you believe science and technology policies are linked with employment policies?

36) Do you believe science and technology policies are linked with economic policies?

37) We thank you if you write any comments or suggestions that will help the accomplishment of this questionnaire objective

ment opportunities after their graduation. The persons interviewed revealed that more attention needs to be paid to engineering and technology, followed by law and humanities, and, lastly, administration, marketing, mathematics and science. Mexico's situation in this regard has improved, particularly in the case of engineering. According to the Graduate Society of Engineering of the National Autonomous University of Mexico (SEFI, in Spanish) [21], Mexico ranked sixth worldwide in the number of graduating engineers. Furthermore, their salaries are significantly greater than their counterparts in the social sciences, which enjoy the highest demand in Mexican universities. It is also important to note that respondents reported, in second place, that there was a need to train humanists. From our perspective, this is not surprising because current economic policy has supported programs in the area of business and economics more than humanities such as history and geography.

The survey also shows that $60 \%$ of the academicians, $100 \%$ of the employers and $60 \%$ of persons employed in the government sector replied that the job market was poor (collectively, $73 \%$ ). In turn, only $27 \%$ considered the job market was saturated, agreeing with the responses provided by colleagues in the survey that,

“....in some areas, the demand for professionals is saturated because it is concentrated in the cities; however, there is an overall lack of professionals at the state level. Some states do not have sufficient doctors, teachers or nurses while there is an overabundance of these professionals at the state level because the problem of unemployment is not taken into account..."

In this regard, it is important to strengthen the design of regional and state policies to address job creation for graduates that is associated with the specific prevailing economic and employment situation of the city, state, region or country in order to provide the needed guidance to consolidate a more vibrant private sector.

Consequently, we note that despite the existence, knowledge and manifestation of an education policy in Mexico, it does not adequately respond to the economic situation of the country. In fact, only $7 \%$ of the respondents responded that it did, while $93 \%$ of respondents considered that Mexico was far from developing an adequate relationship between its education policy and the international economic situation.

Despite conflicting positions, labor and education reforms have recently been passed; however, these reforms await implementation and evaluation to actually determine if they actually promote a stronger manufacturing sector and employment opportunities that permit graduates to more fully participate in a knowledge society, where the role of science and technology is a priority.

The survey also reveals that Mexico faces the major challenge of linking education and employment policies. As mentioned previously, legislative bodies taking up this important topic will fall short if the strategies they develop only centers on the business side of the equation and does not sufficiently consider "quality of life" issues. The persons surveyed also provided the insight that,

“...currently, the primary links are related to the federation's expenditures, but if Mexico possessed a true educational policy, it would link higher education with the government's economic policy and plan accor- 
dingly..."

There are cases where the different actors have become more proactive. On a business level, the program National Council for Labor Competencies (CONOCER, in Spanish) certifies workplace competencies. Its efforts have increased the knowledge of many field workers, improved wages and increased workplace and social recognition. Some important programs in the area of higher education include: the Program for Teacher Improvement (PROMEP, in Spanish), the National System of Researchers (SNI, in Spanish), Academic Bodies (CA, in Spanish), the National Scholarship Program (PRONABES, in Spanish) and the Integral Program for Institutional Fortification (PIFI, in Spanish). But the surveys noted that,

"Unfortunately, persons can infer from the survey that HEIs have not developed sufficient support schemes that promote the employability of their graduates."

\section{Employment Policies}

\section{“...employment policies contribute little to increased productivity ${ }^{6} . "$}

Some particularities are worth highlighting from the perspective of employment. For example, $87 \%$ of respondents acknowledged the existence of employment policies in effect today in Mexico, while $13 \%$ of the participants reported having no knowledge of their existence. Respondents also claimed that present employment policies contribute little to productivity growth, although the current labor reforms have only been in effect for a few months. Also, $80 \%$ of the respondents felt that employment policies have contributed little to productivity growth while $13 \%$ said that there was no contribution, in large part due to the lack of formal employment.

$80 \%$ of respondents report having average-level knowledge and skills required of recent graduates by the labor market, while 20\% mentioned that they had good knowledge and skills. These responses infer that one challenge to be solved is to better link HEIs and businesses, promoting a closer collaboration between the two actors.

According to the data compiled, $87 \%$ of the respondents considered that Mexico's employment policy is not adequate to the economic structure of the country, believing that in the best case it:

“....is the product of a short-term vision that is based exclusively on a market vision that produces irregular and low-quality jobs because a lack of a congruent public policy that promotes the coordinated activity of the sectors involved in economic, industrial and scientific growth and innovation...”

Insofar as the international realm is concerned, the lack of a systemic vision with regards to public policy without a vision for development as a nation has brought the country to economic stagnation, with few protections and with diminished competitive capacity to confront the challenges of a globalized competitive marketplace.

Importantly, 73\% of the survey's participants felt that there is no link between employment and education policies. They believe this situation is due primarily to the fact that it is not sufficient to simply enunciate policies in the realm of public discourse, but to apply them in a consistent and congruent manner. Employment support programs do exist, but solely as social policy. It is believed that newly promoted labor and educational reforms can achieve a synergy between these fields of action, acting as a detonator than can create better jobs. However, only $7 \%$ of the respondents opined that there were identifiable links between employment and education policies. This may be due, in part, to the influence the business sector is exerting on the design of higher education programs, due largely to the Mexican government's strategy to better adapt to global economic dynamics.

On the other hand, it is important to add that $60 \%$ of the respondents believed there is no link between employment and economic policies. They stated that

"The theme of entrepreneurialism has been promoted as an alternative within the employment policy National Institute for the Entrepreneur (INADEM, in Spanish), is an example; however, the economic policy has not sufficiently attended to establishing the necessary regulations to facilitate business creation and survival. Additionally, Small and Medium Enterprises (SMEs) are not targeted to encourage the re-indu-

\footnotetext{
${ }^{6}$ Opinions of subjects surveyed. Surveys were applied to Mexican university administrative and academic personnel, government functiona-
} ries and businessmen, 2013. 
strialization of the country or support the creation of formal and better-paying jobs.”

Importantly, $40 \%$ of the respondents considered that links between employment policy and science and technology do actually exist because of the support provided to small and medium size enterprises (SMEs), as well as diverse projects and government programs. Finally, $60 \%$ of the participants opined that the government does not support SMEs sufficiently.

\section{Economic Policies}

“...Much has been done regarding public economic policy, but it is not enough ${ }^{7}$."

$100 \%$ of respondents expressed they were not only aware of the existence of economic policies currently in operation in Mexico, but also believed that recent reforms will improve income and employment.

Significantly, $67 \%$ of respondents indicated that the government contributes little to increase productivity. In addition to this, subjects also manifested that

“...there is no conductive path between Mexico's economic and employment policies; however, this appears to almost exclusively be a problem of private enterprise. The government appears to only marginally offer training courses. In the end, economic policies do support job creation to the degree that they provide funds to support different sectors, but there is no actual conductive path between economic policy and employment."

This closely coincides with the fact that $67 \%$ of respondents considered that economic policies contribute little to job creation, stating that economic policy has done much, but not enough. Also, $20 \%$ of the respondents manifested that economic policy does contribute significantly to job creation; that obtaining positive results is more probable if these policies generate mechanisms and actions to regulate formal employment.

Additionally, $80 \%$ of the respondents believed that economic policy in Mexico is not adequate because of the great inequality of wages and a significant decrease of formal employment. A similar percentage is observed in terms of the consistency of economic policy in the international arena, revealing not only a domestic disarticulation of policy, but also with international economic policy. This appears to point to a need to improve the relation between higher education and employment.

With respect to this point, one respondent said Mexico continues to follow the neoliberal model, even though developed countries have protectionist policies for their businesses and communities. The neoliberal policy has neglected the issue of developing the domestic market while:

“...it privileges exports at the cost and discontent of the people who suffer from a poor education, a lack of employment opportunities, taxation schemes that do not encourage capitalization of the middle class and high interest rates of the banks for individuals and businesses."

Only $13 \%$ of survey participants believe it is adequate and that it permits stable employment conditions.

As a logical consequence, $73 \%$ of respondents think that Mexico's economic policy is not linked to education policy. However, it is noteworthy to add that $27 \%$ of respondents maintain that they are linked. Nevertheless, $71 \%$ of those taking the survey think that economic policy shows links to employment policy, which stimulates economic growth.

On the other hand, 33\% of the experts surveyed felt that a system of precepts and economic policy criteria must involve organic links between employment policies and science and technology, with science and technology oriented by employment policies. This however does not mean that the links are either consistent or efficient. There are deep contradictions, and the links' inefficiency is notorious in a disarticulation among different policies [10].

\section{Science and Technology Policy}

"Science and technology policy continues to be linked to the topic of education"."

${ }^{7}$ Opinions of subjects surveyed. Surveys were applied to Mexican university administrative and academic personnel, government functionaries and businessmen, 2013.

${ }^{8}$ Opinions of subjects surveyed. Surveys were applied to Mexican university administrative and academic personnel, government functionaries and businessmen, 2013. 
According to the data collected, 93\% of the respondents recognize that there are science and technology policies currently in operation in Mexico. However, the perception of $73 \%$ of the respondents is that the relationship of these policies with employment is far from being considered detectable, as opposed to $27 \%$ who recognize this linkage operates providing opportunities to promote the generation of quality employment opportunities. Furthermore, 73\% reported that science and technology policies contribute little to generate more employment.

Results show that $20 \%$ of respondents reported that science and technology policy contributes to increased productivity in companies because it is essential to boost the country's development. $73 \%$ of the participants noted that the current science and technology policy contributes little to increase productivity because there is no conclusive link between government strategies regarding science and technology and economic, educational and social challenges such a linkage implies. When such contribution exists, it only applies to few sectors of the economy.

As far as the long-term perspectives, $13 \%$ of respondents felt that science and technology policy is suitable for Mexico's economic structure because the greater the investment in quality education and programs for science and technology as an integral part of government policy, the better the opportunities to increase employment opportunities and improve social welfare. However, only $80 \%$ felt that science and technology policies adequately respond to the actual economic situation due to major flaws in how resources are provided and applied. We suppose this is due to a lack of long-term planning which, if better, could permit improved application of strategic development plans.

A relevant fact is that $73 \%$ of respondents felt that the science and technology policy is not adequate for the number of graduates from Mexican institutions of higher education, a figure that is influenced by weaknesses the economic sector suffers regarding science and technology. In this sense, the latest information available shows historic federal budget increases for education, which is apparently linked to the recently passed education reform, which emphasizes basic education, although it does increase the federal budget for higher education. Therefore, while there is a basic and minimal correlation between education, employment and economic policies, based on the legislative reforms that have been recently implemented, it is possible to affirm that an interest in competitiveness and productivity exists, as illustrated by the formation of CEFESCDC, whose mandate is to help create better jobs and a better quality of life for Mexicans.

Mexico's science and technology policy does not seem to be operating closely linked to the international economic situation. 87\% of the persons surveyed opined that the country's policy is not appropriate and that it does not currently reflect any substantial technological change. As a result, they believe that there is little manufacturing of innovative products and few market opportunities, which results in fewer employment opportunities.

Regarding the integration among the public policies assessed, 53\% of the respondents felt that the science and technology policy in Mexico is linked to educational policy, and that this policy has had, without a doubt, important achievements. Over the past three decades, the research capacity of higher education institutions increased significantly in both volume and geographic coverage. Improved administrative practices at the graduate level evolved and have contributed significantly to consolidating the quality of the academic staffs participating in these programs. External evaluations are no longer perceived as aggressions, and the autonomy of institutions of HEIs and their institutional planning presently involves different levels of university management, in conjunction with teachers and researchers.

Significantly, $40 \%$ of the persons interviewed said that the science and technology policy is not linked well with education policy since this link is tenuous in that it only exists to the extent that the National Council for Science and Technology (CONACYT, in Spanish) favors professionals working in the areas of the hard sciences, not knowing exactly how far this trend translates into a science and technology policy. This policy unfortunately places the social sciences on the backburner.

As far as Mexico's science and technology policy having ties with its employment policy, $37 \%$ of respondents agreed that such a link exists. The respondents reported having knowledge of the existence of a national crusade to promote the formalization and expansion of employment, in adherence to the employment policy of President Enrique Peña Nieto in the context of business certification. However, $63 \%$ of the persons interviewed do not recognize the existence of such a link between employment and science and technology policies because most companies tend to lag behind insofar as technological innovation and application is concerned. This makes it difficult to effectively train their personnel in the use of state-of-the-art technologies and results in less efficient production methods and strategies. 


\section{Final Remarks}

The analysis presented in this document shows that the present situation of higher education and employment in Mexico has been changing, although it has not reached equilibrium. It is possible that the recent legislative reforms that have yet to be fully implemented, could foster competitiveness and productivity, and generate better quality employment and better quality of life for Mexicans.

Actually the policies and programs of the Mexican government increase private sector production, as well as science and technology, with marginal possibilities for professional graduates to find employment in these sectors.

The results of this study, based on the perceptions of key actors in higher education, government and business, coincide with the recent study by the OECD [22] in the sense that it is very important to efficiently allocate resources for education to ensure its efficiency and relevance.

The main challenges for the higher education policies in Mexico and their cross cuts with employment, economics and research and development policies, are the following:

- Create strategic vision on the economic development of the country (general, sectoral and regional) and link it with the higher education policies; strengthen capacities of the higher education state system contributing to social and economic development with a long-term vision.

- The economic and higher education policies must reflect the international tendencies in economy, technology transfer and financing.

- It is very important to combine the federal strategies with regional, state, and even city development planes, and avoid the existing imbalances in the labor market in regional context; the consequence of poor alignment is raising unemployment.

- The main policies of higher education, economics and employment must be widely assessed by economic sectors, society, NGOs and academy, to guarantee their interrelation, adequacy, equity and applicability in different geographical and cultural environments.

- The links between business and higher education institutions must be fostered. Education has to be related to the workplace, taking place not only in the classroom, but also in professional practice. The SMEs have to be actively involved in this collaboration.

- Although the research capacity increased significantly in both volume and geographic coverage, the universities must further develop strategic activities in the field of technological innovation, and actively participate in the regional innovation system, carrying out joint projects with businesses and governments, offering high levels of training, consulting services and technological development. This allows students to be a part of academic collaboration groups, in national and international networks, and to contribute to cutting-edge technology topics.

- There are significant advances in the technical careers (e.g. engineers), but the preparation of humanitarians must not be neglected.

- It is very important to promote specific knowledge and capabilities such as teamwork and communication skills, which provide graduates with the necessary resilience in times of rapid, often unpredictable change.

In general, Mexico's higher education policies must provide a strategic vision based on the development of a coordinated industrial policy. It is imperative to improve the balance between supply and demand for professionals graduating from HEIs, whose studies are based on policies designed to improve Mexico's productive structure (with the expected trends as a result of structural reforms) and its integration into the international economy.

\section{References}

[1] UNESCO (2012) Education and Skills for Inclusive and Sustainable Development beyond 2015. http://www.un.org/millenniumgoals/pdf/Think\%20Pieces/4_education.pdf

[2] UNESCO (2012) Los jóvenes y las competencias. Trabajar con la educación. UNESCO, Paris.

[3] Burnett, N. (2008) The New Dynamics of Higher Education: Meeting the Challenges of Equity, Quality and Social Responsibility. OECD/France International Conference-Higher Education to 2030: What Futures for Quality Access in the Era of Globalization? http://unesdoc.unesco.org/images/0018/001808/180891e.pdf

[4] Aréchiga, H. (1998) La ciencia como factor de integración en Latinoamérica. En: La Ciencia en la integración latinoamericana, Memoria, Ciencia y Desarrollo, Serie Encuentros, CONACYT, México City, 11-12. 
[5] Cimoli, M., Holland, J.M., Porcile, G., Primi, A. and Vergara, S. (2006) Growth, Structural Change and Technological Capabilities: Latin America in a Comparative Perspective. Working Paper Series No. 11, Laboratory of Economics and Management, Santa Ana School of Advanced Studies, Pisa.

[6] López Segrera, F. (2008) Tendencias de educación superior en el mundo y en América Latina y el Caribe. Revista de Avalicao da Educao Superior, 13, 267-291. http://dx.doi.org/10.1590/S1414-40772008000200003

[7] Moreno-Brid, J.C. and Ruíz-Naples, P. (2009) La educación superior y el desarrollo económico en América Latina. CEPAL, Santiago de Chile.

[8] Cogan, J.J. and Kennedy, K.J. (2004) Schooling for the Future in Asia Pacific: Six Cases. International Journal of Education Research, 41, 503-511. http://dx.doi.org/10.1016/j.ijer.2006.02.004

[9] Rangel Delgado, J.E. and Ivanova Boncheva, A. (2008) Educación Superior y Empleo en dos economías de la Cuenca del Pacífico: Casos México y Tailandia. Universidad de Colima, México.

[10] Delgado, J.E.R. and Boncheva, A.I. (2012) The Crisis in Two Pacific Rim Economies Higher Education and Employment in Mexico and Thailand. Witpress Southampton, Boston.

[11] Asian Development Bank (ADB) (2012) Improving Transitions from School to University to Workplace. http://web.edu.hku.hk/staff/gerry/docs/Improving_Transitions_2012_06.pdf

[12] Dutrenit, G. (2006) Bases y mecanismos para una política de ciencia, tecnología e innovación en México. Foro Consultivo, Científico y Tecnológico, México.

[13] Agren, D. (2012) Big Changes in Mexico Labor Laws Are First in 40 Years. USA Today.

[14] Tuirán, R. (2012) La educación superior en México 2006-2012. Un balance inicial. Observatorio Académico. http://red-academica.net/observatorio-academico/2012/10/03/la-educacion-superior-en-mexico-2006-2012-un-balanceinicial/

[15] Sharma, Y. (2013) A Focus on Skills Increasingly Links Higher Education with Employment. University World News. http://www.universityworldnews.com

[16] EFE (2013) El desempleo en Japón se redujo en septiembre una décima y se situó en el 4\%. http://cincodias.com/cincodias/2013/10/29/empresas/1383027549_812737.html

[17] ANUIES (2013) Educación, Mercado de Trabajo, Satisfacción Laboral. ANUIES, México.

[18] Trading Economics (2013). http://es.tradingeconomics.com/russia/unemployment-rate

[19] Index Mundi (2013) China Tasa de desempleo. http://www.indexmundi.com/es/china/tasa_de_desempleo.html

[20] Trading Economics (2013). http://es.tradingeconomics.com/south-korea/unemployment-rate

[21] SEFI (2012) México se ubica en el 6to lugar mundial con mayor número de ingenieros graduados. Sociedad de Exalumnos de la Facultad de Ingeniería de la Universidad Nacional Autónoma de México. http://sefi.org.mx/noticias-y-actividades/2012/04/13/mexico-se-ubica-en-el-6to-lugar-mundial-con-mayor-numero-de-i ngeni

[22] OECD (2013) Education at a Glance 2013: OECD Indicators. OECD Publishing, Paris. 